\title{
Hazard and Risk Assessment from Hurricane Ivan (2004) in Grenada using Geographical Information Systems and Remote Sensing
}

\author{
FAKHAR KHALID and RENEE BABB \\ Centre for GIS and Remote Sensing, University of Greenwich, Medway Campus, Kent, ME4 4TB, UK; \\ f.khalid@greenwich.ac.uk \\ (Received 30 ${ }^{\text {th }}$ May 2008; Revised $16^{\text {th }}$ December 2008; Accepted $18^{\text {th }}$ December 2008)
}

\begin{abstract}
Hurricanes are destructive storms with strong winds, intense storm surges, and heavy rainfall. The resulting impact from a hurricane can include structural damage to buildings and infrastructure, flooding, and ultimately loss of human life. This paper seeks to identify the impact of Hurricane Ivan on the affected population of Grenada, one of the Caribbean islands. Hurricane Ivan made landfall on $7^{\text {th }}$ September 2004 and resulted in $80 \%$ of the population being adversely affected. The methods that were used to model these impacts involved performing hazard and risk assessments using GIS and remote sensing techniques. Spatial analyses were used to create a hazard and a risk map. Hazards were identified initially as those caused by storm surges, severe winds speeds, and flooding events related to Hurricane Ivan. These estimated hazards were then used to create a risk map. An innovative approach was adopted, including the use of hillshading to assess the damage caused by high wind speeds. This paper explains in detail the methodology used and the results produced.
\end{abstract}




\section{Introduction}

Tropical cyclones are defined as "non-frontal synoptic scale low-pressure systems over tropical or sub-tropical waters with organised convection and definite cyclonic surface wind circulation" (Atlantic Oceanographic and Meteorological Laboratory, 2007). Hurricane is the name given to tropical cyclones formed over the North Atlantic, North-east Pacific, and South Pacific oceans (Atlantic Oceanographic and Meteorological Laboratory, 2007).

The conditions for hurricane formation are sea surface temperatures of at least $27^{\circ} \mathrm{C}$, regions of relatively low surface air pressures, a Coriolis Force resulting from the rotation of the earth, unstable conditions within the troposphere, an absence of strong vertical wind shear, and the release of latent heat within clusters of clouds.

Hurricanes are typically $600 \mathrm{~km}$ wide with sustained wind speeds of over $119 \mathrm{kph}$. They rotate in an anti-clockwise direction in the Northern Hemisphere and a clockwise direction in the Southern Hemisphere. The distinctive features of a hurricane are the eye, eye walls, and the spiral bands (Aguado and Burt, 2007).

Hazards have either the potential to, or after occurring, do in fact disrupt the normal functioning of social systems and can result in human injury or death (Showalter, 2001). The primary impact from hurricanes is immediate and direct resulting from the effects of strong winds, heavy rainfall, and storm surge.

Risk is defined as that which involves the likelihood of harm or other form of loss (Carson, 1996). There is a relationship between hazard and risk which is dependent on vulnerability. There is no risk if there are hazards but no vulnerability, or if there is vulnerability but no hazard (Blaikie et al., 2003). Risk is therefore a product of both hazard and vulnerability.

\section{$1.1 \quad$ Study area}

Grenada is a small Caribbean island located between latitudes $11^{\circ} 59^{\prime}$ and $12^{\circ} 20^{\prime} \mathrm{N}$ and longitudes $61^{\circ} 36^{\prime}$ and $61^{\circ} 48^{\prime} \mathrm{W}$. The island is $18 \mathrm{~km}$ wide 
and $34 \mathrm{~km}$ long with a total land area of $312 \mathrm{~km}^{2}$ (Organisation of Eastern Caribbean States, 2004).

Grenada has a population of 102,632 as taken from the Grenada Population and Housing Census in 2001 (Organisation of Eastern Caribbean States, 2004). This population is mainly distributed on the coastal fringes and covers $110 \mathrm{~km}^{2}$ of land, with the population mainly distributed along the coastal fringes. The remainder of the island is unoccupied and comprises steep mountainous terrain covered in vegetation.

On $7^{\text {th }}$ September 2004, Hurricane Ivan ravaged Grenada for 6 daylight hours (World Bank, 2004). With wind speeds in excess of $217 \mathrm{kph}$, this hurricane was rated a Category 3 on the Saffir-Simpson Hurricane Scale (Organisation of Eastern Caribbean States, 2004).

After the complete passing of Hurricane Ivan, a national assessment was performed, which indicated that $80 \%$ of the population had been affected and that the cost of the damage was estimated to be twice the annual national Gross Domestic Product of Grenada (Organisation of Eastern Caribbean States, 2004).

\subsection{Purpose of study}

This paper seeks to identify the impact of Hurricane Ivan on the population of Grenada through hazard and risk assessments. The results of these assessments indicate how much of the population of Grenada was affected by the physical impact from Hurricane Ivan (see main map), and does not include other impacts such as socio-economic and psychological, which were all assessed by the Organisation of Eastern Caribbean States in 2004. 


\section{Methods}

\subsection{Hazard mapping}

There were three types of hazards that were mapped: floods, storm surge, and wind exposure. The hazard mapping involved spatial analysis techniques which utilised a Shuttle Radar Topography Mission (SRTM) 90-metre digital elevation model (DEM) to delineate the flood-prone areas within Grenada. The SRTM DEM was used initially to calculate the flow direction of surface water. As water flowed down the slopes, flow direction was measured by changing elevation values in the DEM. The flow direction surface was then used to measure the overland flow accumulation. The flow accumulation surface represented the total amount of water flowing into each cell of the DEM. This accumulated amount of water in each cell was calculated by using the direction of the flow of water from one cell to another. Combination of flow direction and flow accumulation surfaces were then used to produce an estimation of the current stream network. These results were used to delineate watershed areas for the entire island to estimate the sizes of the catchment areas of the surface waters. Storm surge mapping involved combining average tidal predictions with the various storm surge values to create a total storm surge calculation, from which they were then identified on the island using the DEM.

Finally, wind exposure mapping was performed by using the hillshading technique. A hillshade tool was created to identify locations on a digital elevation model that would be in the direct path of sun rays and those areas that would fall in shadow. This tool was applied to wind blowing over land enforcing the theory that there would be no areas sheltered from hurricane winds. The analysis therefore involved wind blowing from all compass directions and altitudes producing many maps showing varying degrees of possible wind damage to the entire island.

\section{$2.2 \quad$ Risk mapping}

The first step involved in risk mapping was determining the vulnerable regions within the island. This was accomplished by extracting the populated areas from the high resolution satellite imagery. The risk areas 
were then created by intercepting those vulnerable areas with the hazard areas to the produce flood risk, storm surge, and wind damage maps for Grenada. The main map shows four maps depicting the locations of the vulnerable populations.

\section{Conclusions}

The results from this research, as seen in the maps, show that the areas affected from severe flooding totals $91 \mathrm{~km}^{2}$, which is approximately $82 \%$ of the total populated areas of the country. A total area of $0.25 \mathrm{~km}^{2}$ was inundated by storm surges for terrain elevations up to and including $18 \mathrm{~m}$. The entire country experienced wind damage because the wind was not from one direction alone, nor from one altitude, thereby causing catastrophic damage island-wide. These figures indicate the degree of the damage caused after the passing of Hurricane Ivan.

The map is quite important to future hurricane hazard planning for Grenada because it highlights that populated areas located along the coastal fringes of the island and along natural water courses are the most vulnerable areas to flooding, storm surges, and wind damage. The map is a useful tool that can be used to show the locations and magnitudes of damage caused by a Category 3 hurricane, as well as estimate the damage that would be caused by hurricanes of lesser strengths.

With respect to alleviating damage from hurricane winds, building regulations should be created and enforced to ensure a minimal level of defence against hurricane force winds. It is therefore necessary to use these findings as a benchmark for preparations to be made for disaster mitigation, management, and preparedness. Further analysis can be performed using higher resolution DEMs as well as including drainage elements within the country such as suck wells, which are used to collect surface run-off, to obtain a more accurate depiction of flood areas. 


\section{Software}

The software used to obtain the results of this research included Erdas Imagine 9.1, ER Mapper, ArcGIS 9.2 and Microsoft Office Excel. Erdas Imagine 9.1 and ER Mapper were used to perform corrections to the SRTM $90 \mathrm{~m}$ DEM data, which was used in the flood and storm surge delineation models and the wind exposure model. ArcGIS' Spatial Analyst was used to extract the inundation areas from flooding and storm surge and the possible degree of exposure from the wind forces. Microsoft Excel was used to create charts showing the relationship between the various heights of the storm surge, the maximum distance inland from the coast that inundation will occur, and the terrain elevation.

\section{Acknowledgements}

We wish to thank the University of Greenwich, Medway Campus, GeoOrbis, Inc., the United Nations Development Programme (UNDP) and DigitalGlobe for providing us with the resources needed to complete this paper.

\section{References}

AGUADO, E. and BURT, J. E. (2007) Understanding Weather and Climate, Prentice Hall, New Jersey, U.S.A.

ATLANTIC OCEANOGRAPHIC AND METEOROLOGICAL LABORATORY (2007) Frequently Asked Questions, Available online at: Atlantic Oceanographic and Meteorological Laboratory National Oceanic and Atmospheric Administration, Miami, Florida, U.S.A. http://www.aoml.noaa.gov/hrd/tcfaq/tcfaqHED.html [Accessed: 6th June 2007].

BLAIKIE, P. M., CANNON, T., DAVIS, I. and WISNER, B. (2003) At Risk: Natural Hazards, Peoples Vulnerability and Disasters, Taylor and Francis, London. 
CARSON, D. (1996) Risking Legal Repercussions, In Good Practice in Risk Assessment and Risk Management (Eds., Kemshall, H. and Pritchard, J.), Jessica Kingsley Publishers Ltd, London, England.

ORGANISATION OF EASTERN CARIBBEAN STATES (2004) Grenada: Macro-Socio-Economic Assessment of the Damages Caused by Hurricane Ivan, Available online at: Organisation of Eastern Caribbean States, Castries, St. Lucia. http://www . oecs .org/Documents/GrenadaReport/GRENADAREPORT . pdf [Accessed: 6th June 2007].

SHOWALTER, P. S. (2001) Remote Sensings Use in Disaster Research: A Review, Disaster Prevention and Management, 10(1), 21-29.

WORLD BANK (2004) Grenada Preliminary Damage Assessment, September 17, 2004, Available online at: The World Bank, Washington, D.C., U.S.A. http://siteresources.worldbank.org/INTDISMGMT/ Resources/grenada_assessment.pdf [Accessed: 4th June 2007]. 